\title{
Health Disparities and Historical Injustice in Sierra Leone: A Case for Reparations?
}

\author{
Stacy Elmer
}

You would rather have a Lexus or justice, a dream or some substance? A Beamer, a necklace, or freedom?

—Dead Prez, "Hip-Hop"

\section{INTRODUCTION}

In 2000, the World Health Organization ranked Sierra Leone as the country with the least efficient health system of any country in the world. ${ }^{1} \quad$ With sixty-eight percent of its population living below the poverty line, Sierra Leone is ranked 176th, or second to last, on the United Nations Development Programme Human Development Index. ${ }^{2}$ Malnutrition and malaria are leading causes of death, and life expectancy at birth is thirty-seven years for males and forty years for females, ${ }^{3}$ equivalent to half of the life expectancy for persons living in the United States at seventy-five years for males and eighty years for females. ${ }^{4}$ The high rates of mortality in Sierra Leone are attributed to conditions that have not been a public health concern in the United States for half of a decade. Mortality rate is only one of the many indicators of poor health status in Sierra Leone. Various explanations have been proposed to

* Ph.D. candidate 2010, University of Kansas Department of Philosophy; B.A. 2004, The Colorado College. I would like to extend a special thank you to Professor Derrick Darby for his direction and his support of this philosophical project.

1. World Health Org., The World Health RePOrt 2000: Health Systems: Improving PERFORMANCE, 182 annex, tbl.5 (2000), available at http://www.who.int/entity/whr/2000/en/ whr00_en.pdf.

2. World Health Org., Health Action in Crises: Sierra LeOne, (2007), available at http://www.who.int/entity/hac/crises/sle/background/Sierra Leone_Apr07.pdf.

3. World Health Org., Country Health System Fact Sheet 2006: Sierra Leone (2006), available at http://www.afro.who.int/home/countries/fact_sheets/sierraleone.pdf.

4. World Health Org., Mortality Country Fact SheEt 2006: United States of AMERICA (2006), available at http://www.who.int/whosis/mort/profiles/mort_amro_usa_unitedstates ofamerica.pdf. 
explain the causes of those indicators, including inadequate access to land and other rural assets, ${ }^{5}$ fighting and displacement as a result of the country's civil war, ${ }^{6}$ and ignorance. ${ }^{7}$ Yet, efforts designed to address these causes have been shown to be only mildly effective in decreasing overall health disparities between Sierra Leone and other nations.

This Article will address the underlying causes of the drastic inequalities in health between populations in Sierra Leone and nations such as the United States, and explore whether reparations are a viable option for addressing these inequalities. Using a cosmopolitan framework it concludes that while reparations are not morally required by nations such as the United States for their involvement in Sierra Leone's legacy of historical injustice, there is a moral obligation generated by the growth of global interconnectedness that applies universally and demands a reconfiguration of social and political boundaries and a redistribution of sovereignty amongst communities, nations, multinational unions, and international diplomacies to address adequately the growing health inequalities between nations that suffer from disparate health conditions, such as Sierra Leone, and more developed nations, such as the United States.

\section{THE CONCEPT OF REPARATIONS}

Reparations are one way to address what is owed for a legacy of injustice. Historically, reparations have been considered as a form of redress for three types of injustice: slavery, ${ }^{8}$ colonialism, ${ }^{9}$ and conflict. ${ }^{10}$

5. Adelmuhsin M. Al-Sudeary, The Need for an Exclusive Focus: The Rural Poor, http://www.cads-sierraleone.org/ifadontheruralpoor.htm (last visited Feb. 19, 2009).

6. Simon Rushton, Health and Post-Conflict Stability: The Case of Sierra Leone 3-7 (Mar. 1, 2005) (unpublished comment), available at $\mathrm{http}: / / \mathrm{www}$.allacademic.com $/ / \mathrm{meta} / \mathrm{p}$ _mla_apa_research _citation/0/7/1/1/1/pages71114/p71114-1.php.

7. Science-based medicine is not widely accepted in Sierra Leone. In many parts of Sierra Leone, hospitals are perceived as places where patients go to die. See Medecins Sans FrontiERES, LeSSONS FROM PAin: TREATING SiERRA LeONE's ENDLESS Health EMERGENCY 12 (2006), available at $\mathrm{http} / / / \mathrm{www} . \mathrm{msf}$. org/source/countries/africa/s-leone/2006/Lessons_from_pain_final.pdf (discussing the state of healthcare in Sierra Leone)

8. See, e.g., Roy L. Brooks, Atonement AND Forgiveness 2-4, 180-206 (2004); Alfred L. Brophy, ReParations PRo \& CON: A NeW MOdel FOR BlaCK REPARATIONS 55-74, 75-94 (2006); John Torpey, Making Whole What Has BeEn SMashed: On Reparations Politics 116-32 (2006); see generally DAVID HOROWITZ, UNCIVIL WARS: THE CONTROVERSY OVER REPARATIONS FOR SLAVERY (2003).

9. See generally RHODA E. HOWARD-HASSMANN, REPARATIONS TO AFricA (2008); Reparations for Indigenous Peoples: International and Comparative Perspectives (Federico Lenzerini ed., 2008).

10. See Office of the U.N. High Comm'r for Human Rights, Rule-of-Law Tools for PostConflict States: Reparations Programmes, 1-3, U.N. Doc. HR/PUB/08/1 (2008). 
One method used to assess what is owed for historical injustice is to look to the past to determine the causal factors responsible for the resulting harms.

For instance, until recently the U.S. government has been reluctant to admit publicly its role in the injustices caused to blacks during slavery and Jim Crow. ${ }^{11}$ On July 29, 2008, the U.S. House of Representatives passed a resolution formally apologizing for slavery. ${ }^{12}$ Yet reparations were not included in the resolution as a viable or necessary accompaniment for addressing what is owed to blacks for the legacy of slavery and the discriminatory laws that followed. Thus, while the U.S. government issued an apology for its role in the promotion of past racial injustice, it failed to provide further reparative measures to cope with racial inequalities.

While reparations have been implemented successfully to redress past injustice in countries such as Peru, South Africa, and Sierra Leone, difficulties in identifying who is responsible for slavery's harms and who should be considered its modern victims (and as such, who are appropriate recipients of reparations) cause ongoing dispute over reparations for slavery in the United States.

Currently in Sierra Leone, reparations are being provided by the Sierra Leone government to victims of the country's most recent civil war. ${ }^{13}$ In 1991, poverty and political unrest catalyzed a ten-year war led by the Rebel United Front (RUF). Characterized by abductions of women and children, indiscriminate amputations, cannibalism, sexual violence, and recruitment of child soldiers, the war produced widespread human rights violations. The Lomé Peace Accord was signed in 1999 declaring a ceasefire between warring parties and endowed the United Nations with the power to uphold peace within the country. The RUF violated the treaty and fighting continued until 2002 when President Kabbah declared an official end to the war. ${ }^{14}$

11. No formal reparations have been offered for slavery in the United States, although there are extensive arguments for and against. ANDREW WOOLFORD \& R.S. RATNER, INFORMAL

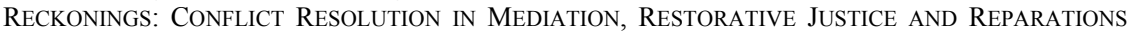
128 (2007); Rhodri C. Williams, Post-Conflict Property Restitution in Bosnia: Balancing Reparations and Durable Solutions in the Aftermath of Displacement (Dec. 5, 2006) (unpublished comment), available at http://www.brookings.edu/speeches/2006/ /media/Files/rc/speeches/2006/ 1205property/200612_rcw_TESEVpresentation.pdf.

12. H.R. Res. 194, 110th Cong. (2008).

13. See generally Truth AND ReConciliation Comm'n, SierRa LeOne, Witness to Truth: REPORT OF THE SieRRA LEONE TRUTH AND RECONCILIATION COMMISSION (2004) [hereinafter TRUTH \& RECONCILIATION COMM'N], available at http://www.trcsierraleone.org/drwebsite/publish/ index.shtml.

14. See Sierra Leone-UNOMSIL, Background, http://www.un.org/Depts/DPKO/Missions/ 
The Lomé Peace Accord called for the creation of the Truth and Reconciliation Commission of Sierra Leone (TRC) and the Special Court of Sierra Leone. Both entities were designed to facilitate reconciliation between perpetrators and victims of the war. ${ }^{15}$ The TRC was charged with addressing and recommending measures appropriate to the rehabilitation of victims of human rights violations and to restore dignity to the war's victims. The TRC responded by designing and implementing a program of reparations. ${ }^{16}$ The program included health provisions, such as free health care for amputees and physical health care for the war wounded, ${ }^{17}$ designed to address both harms to the health of individuals as well as damages to the country's overall health systems resulting from the war. ${ }^{18}$ The program also demanded that the government finance health initiatives with built in systems of oversight. ${ }^{19}$

While developing the reparations program, the TRC recognized the existence of many pre-existing barriers to the effective implementation of the health provisions. These barriers included a shortage of medical professionals, ${ }^{20}$ an absence of publicly funded access to health care, and a lack of health care facilities. ${ }^{21}$ While a reparations program was recommended by the TRC, the presence of pre-existing structural barriers both influenced the TRC's design of the recommendations and further limited the government's ability to implement successfully many of the proposed recommendations. ${ }^{22}$

In sum, while reparations were provided to redress harms resulting from the country's recent conflict, the state of health and healthcare in Sierra Leone was already damaged severely prior to the onset of the war. ${ }^{23}$ Consequently, these pre-existing conditions served as barriers to the TRC's ability to form adequate recommendations and subsequently

unomsil/UnomsilB.htm

15. For a full account of the proceedings and recommendations of the TRC and the Special Court, see TRUTH \& RECONCILIATION COMM'N, supra note 13, vol. 2, ch. 4.

16. For a full description of the legal basis, guiding principles, beneficiaries, and implementation recommendations, see $i d$.

17. $I d$.

18. Id.

19. $I d$.

20. In 2004, the World Health Organization (WHO) reported a total of 168 physicians in Sierra Leone, servicing a population of over 5.5 million. WORLD HEALTH ORG., supra note 3.

21. In 2006, the WHO estimated that there were less than twenty-five hospital beds per 10,000 people in Sierra Leone. Id.

22. Id.

23. For instance, the under-five mortality rate was higher in 1980 than it was at the height of the war. $I d$. 
prevented the TRC from demanding and providing full redress for the war's victims.

\section{THE HISTORY OF INJUSTICE IN SIERRA LEONE}

Whether on the national or international level, policy discussions regarding what nations are obligated to provide one another often neglect historical legacies and their connections to modern-day poverty. For instance, while reparations for Sierra Leone's recent history of innercountry fighting has been addressed publicly by the TRC within the country, the complete historical legacy of injustice in Sierra Leone, which includes slavery and colonialism as well as conflict, remains unaddressed by the global community. Although both slavery and colonialism in Sierra Leone were perpetrated by some of the world's most affluent nations and may have contributed significantly to the current state of poor health and health care in Sierra Leone, the effects of colonialism and slavery are no longer considered as subjects appropriate for redress.

As early as the 1460 s, Sierra Leone was being used as a central trading point for African kings selling slaves to European traders and remained a prominent port of departure for slave ships headed for the United States. ${ }^{24}$ Thousands of African rice farmers and their families were sent by the British from Bunce Island off the coast of Sierra Leone to plantations in South Carolina, Florida, and Georgia. ${ }^{25}$ Bunce Island was also a popular site for the purchase of African slaves by American slave traders from Massachusetts, Rhode Island, and Connecticut. ${ }^{26}$

During the abolition of slavery in England, a settlement was established on the coast of Sierra Leone for "London's Black Poor," a term that was synonymous at the time with recently freed slaves. ${ }^{27}$ The "Province of Freedom," as the British called it, eventually became a permanent settlement for freed slaves returned to Africa from both England and the United States under the auspice of repatriation. ${ }^{28}$ Either

24. For a thoughtful treatment of the role of the United States in the slave trade in Sierra Leone,

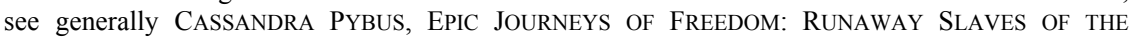
AMERICAN REVOLUTION AND THEIR GLOBAL QUEST FOR LIBERTY (2006).

25. Bunce Island: A British Slave Castle in Sierra Leone, http://www.bunceisland.org/index.html (last visited Feb. 10, 2009).

26. $I d$.

27. Tara Helfman, The Court of Vice Admiralty at Sierra Leone and the Abolition of the West African Slave Trade, 115 YALE L. J. 1122, 1127-28 (2006).

28. Id. at 1129; see also Jeremy I. Levitt, Illegal Peace?: An Inquiry Into the Legality of Power-Sharing with Warlords and Rebels in Africa, 27 MicH. J. INT'L L. 495, 508-09 (2006) 
afraid or unable to return to their original countries, many freed slaves stayed in Sierra Leone and settled in the city of Freetown. ${ }^{29}$ Thousands of slaves shipped to the United States and returning home to Africa passed through Freetown's port. ${ }^{30}$ While its use as a slave trading post ended in the mid-1800s, British colonization lasted until Sierra Leone gained its independence in $1961 .^{31}$

The most recent civil war erupted in 1991 between the Sierra Leone military and the Revolutionary United Front (RUF) and left thousands wounded and starving. ${ }^{32}$ Disarmament occurred in 2002 led by U.N. Peacekeepers, and since then Sierra Leone has remained stable. While injustice in Sierra Leone is most often associated with this recent conflict, slavery and colonialism may be the causal factors underlying the country's present state of poor health. Tracing the lasting impact of slavery and colonialism to present day poverty remains a difficult project. While the history of Sierra Leone is wrought with injustice based on racial, ethnic, and political distinctions, and several countries are implicated in these harms, identifying the roots of the legacy of historical injustice in Sierra Leone using a backward-looking approach as motivation for claims for redress is rejected by appeal to the legal principles of clear causality and statute of limitations.

Although there exist serious inequalities in health between developed nations such as the United States and less developed nations such as Sierra Leone, it is common for the difference to be explained predominantly as a result of poor governmental oversight and political and economic instability in the less developed nations, not to historical injustice. ${ }^{33}$ While the staggering rates of infant and maternal mortality

(discussing the cultural development of Sierra Leone)

29. See Visit Sierra Leone, Freetown, http://www.visitsierraleone.org/freetown.asp (last visited Feb. 3, 2009). Freetown remains the capital of Sierra Leone. CIA-The World Factbook, Sierra Leone, https://www.cia.gov/library/publications/the-world-factbook/geos/sl.html (last visited Feb. 3, 2009).

30. See generally Visit Sierra Leone, supra note 29 ("Freetown hosts the third largest natural harbour in the world. ... Thousands of slaves were returned to or liberated in Freetown.").

31. Rena L. Scott, Moving from Impunity to Accountability in Post-War Liberia: Possibilities, Cautions, and Challenges, 33 INT'L J. LEGAL INFO. 345, 359 (2005); see Levitt, supra note 28, at 508 n.46.

32. Noah B. Novogrodsky, Speaking to Africa-The Early Success of the Special Court for Sierra Leone, 5 SANTA ClaRA J. INT'L L. 194, 196-98 (2006). The RUF was comprised of rebels from both Liberia and Sierra Leone. See Scott, supra note 31, at 359-60.

33. See, e.g., Inter Press Service, Building Peace in Sierra Leone, Hum. RTS. TRIB., Sept. 3, 2008, http://www.humanrights-geneva.info/Building-peace-in-Sierra-Leone,3415 (reporting that foreign governments and non-government organizations have questioned Sierra Leone government oversight and accountability regarding the use of aid leaving the "country's educational and health sectors ... in dire straits"); see also Julia Mackenzie, Sierra Leone's Failing Health, BBC News, 
rates are highlighted in newspapers, ${ }^{34}$ and American television is inundated with ways to donate to charitable organizations such as the Gap's "Go Red" and "Feed the Children," 35 donations to these types of organizations are generally perceived as acts of charity. Typically the motivation for individuals providing such gifts does not stem from their recognition of a moral obligation generated by what countries owe one another, ${ }^{36}$ as few Americans consider it their moral obligation to contribute to the elimination of global health inequalities, and even fewer Americans view themselves as in any way implicated in the development of such inequalities.

Morality, however, is concerned with what should be the case. Just because there are not currently laws and social institutions enforcing policies that aim to reduce health inequalities between countries does not mean that there should not be. What should be the case does not matter to a dying child in Sierra Leone unless it actually is the case. Thus, once moral obligations are established, it is imperative that these obligations become socially instituted and acted upon.

Setting forth a convincing moral argument for what should be the case justifies morally the institution of new mandates and laws addressing health inequalities. The utilitarian position states that we have a duty to provide assistance until giving any more would require giving away something of moral significance. ${ }^{37}$ Thus, spending money on a ticket to the opera or a new shirt is not justified if there are children in the world that would benefit from the supply of food or medicine that could be purchased with the money spent on the opera ticket or the shirt. Another argument provided by the libertarian position claims that our only moral duties are negative duties not to harm others. ${ }^{38}$ Libertarians

Jan. 4, 2007, http://news.bbc.co.uk/2/hi/programmes/newsnight/6231905.stm ("The healthcare system was largely destroyed in the war along with much of the other vital infrastructure. Now the Sierra Leone government is struggling to improve facilities - many of which were burnt down or destroyed.").

34. For a recent report on infant and maternal health care in Sierra Leone, see Kevin Sullivan, $A$ Mother's Final Look at Life: In Impoverished Sierra Leone, Childbirth Kills One in Eight Women, WASH. POST, Oct. 12, 2008, at A1.

35. See Product Red, http://www.joinred.com/Home.aspx (last visited Feb. 5, 2009); Feed the Children, http://www.feedthechildren.org (last visited Feb. 5, 2009).

36. Peter Singer, Famine, Affluence, and Morality, 1 PhIL. \& Pub. AfF. 229, 235 (1972).

37. See Peter Singer, The life You Can Save: Acting Now to End World Poverty (forthcoming Mar. 2009); Singer, supra note 36, at 233-34; Peter Singer, The Singer Solution to World Poverty, N.Y. TiMES, Sept. 5, 1999, (Magazine) at 60-63.

38. For an account of the libertarian view on what we owe the world's disadvantaged, see Loren Lomasky, Liberty and Welfare Goods: Reflections on Clashing Liberalisms, 4 J. ETHICS 99, 104-05 (2000), and THE LIBERTARIAN READER: ClassiC AND CONTEMPORARY WRITINGS FROM LAO-TZU TO MiLton FrIEDMAN passim (David Boaz ed., 1997). 
deny both the duty to assist starving people in other countries and the duty to provide welfare provisions to fellow citizens.

I argue on cosmopolitan grounds that our rapidly globalizing world requires us to think seriously about what moral obligations are demanded of individuals to promote the health and welfare, not only of our fellow citizens of the United States, but also of individuals across the globe. Cosmopolitanism generates moral duties to eradicate health inequalities around the globe that recognize the ways in which decision-making reaches beyond national boundaries, without explicit reference to an individual's or a nation's involvement in past injustice.

\section{THE FRAMEWORK OF COSMOPOLITANISM}

The term "cosmopolitanism" refers to a variety of views, all of which are characterized by some form of commitment to a universal community inclusive of all human beings. ${ }^{39}$ The form of moral cosmopolitanism considered here takes the fulfillment of basic human rights for every individual as the primary object of moral importance to assess what sorts of duties and obligations are justified for addressing inequalities in health between individuals across the globe.

The goal of this Article is not to defend a theory of rights, but instead to make the forthright claim that if we are committed to respecting the basic human rights of all persons, there must be widespread acknowledgement of the universal moral community in which all persons participate in a unified institutional scheme.

I borrow from Thomas Pogge three elements shared between all types of cosmopolitan theory:

1. Individualism: Individual human beings are the ultimate unit of moral concern, rather than families, ethnic groups, or nation groups.

2. Universality: Individual human beings as ultimate units of moral concern applies equally to everyone, instead of to a subset of individuals based on gender, race, religion, etc.

3. Generality: Individual human beings, universally, are the ultimate units of moral concern for everyone. Thus, I am of equal moral

39. Cosmopolitanism has various contemporary forms-legal, moral, cultural, economic, etc. This Article focuses exclusively on moral cosmopolitanism. For a thorough study of cosmopolitanism, see generally CONCEIVING COSMOPOLITANISM: THEORY, CONTEXT, AND Practice (Steven Vertovec \& Robin Cohen eds., 2002); Robert Fine, Cosmopolitanism (2007). For an excellent discussion of cultural cosmopolitanism, see generally KWAME ANTHONY APPIAH, COSMOPOLITANISM: ETHICS IN A WORLD OF STRANGERS (Henry Louis Gates Jr. ed., 2006). 
concern to everyone, equally, not only to my fellow Americans or my fellow worshippers, for instance. ${ }^{40}$

For all cosmopolitans, human beings are the primary unit of moral concern, and no individual is worth more than any other. The principle of equal worth of persons accords with a basic moral intuition that no one person is arbitrarily more valuable than another, and has been used to justify policies that ensure everyone receives equal treatment. However, cosmopolitanism is often rejected on these very grounds.

If the cosmopolitan is truly committed to treating all individuals equally, he must be willing to endorse a principle of impartiality; in other words, he must be committed to rejecting differential treatment of any two individuals. The objection goes that for the cosmopolitan, one has the same moral obligations to ensure the health and well being of a child in Africa as one does to a child in America; an obligation to treat one's husband, wife, or child the same as a stranger's. It is because there is a competing moral intuition that tells us that it should be permissible to treat our loved ones differently from strangers that we hesitate to endorse fully the principle of impartiality. Thus, problematic for the cosmopolitan is that either we are committed to equality of persons and thus treat every individual the same, or we treat our loved ones with special consideration, thereby attributing greater worth to our loved ones than to strangers. On the basis of these conflicting principles, cosmopolitanism is often rejected.

Partiality is a concern of individual justice. For instance, when individual $\mathrm{A}$ is comparing his treatment of two different individuals, $\mathrm{B}$ and $\mathrm{C}$, to evaluate whether or not he is treating $\mathrm{B}$ with the same moral concern as he is treating $\mathrm{C}$, he is concerned about what justice requires of individuals. The principles of justice that govern treatment between individuals are different than those that govern the development of a just institutional scheme. ${ }^{41}$ According to John Rawls, there are certain rules regarding the conduct of individuals within a shared society that generate duties and obligations that determine morally appropriate ways for individuals to treat one another. ${ }^{42}$ There are different principles of justice that preside over the development of the scheme of institutions that govern a society. These principles are not concerned with the treatment of individuals amongst one another per se, but are concerned instead with the economic, social, and legal ground rules that determine

40. Thomas W. Pogge, Cosmopolitanism and Sovereignty, 103 ETHICS 48, $48-49$ (1992) [hereinafter Pogge, Cosmopolitanism].

41. John RAWls, A TheORY OF JUSTICE 5 (rev. ed. 1999).

42. Id. at 4 . 
how goods and services, including rights and liberties, are distributed amongst a society. The key idea of institutional justice is that the institutional scheme ensures a certain set of rights and liberties for all. The purpose of the institutional scheme is in part to ensure that no matter what actions an individual takes, if one is living within the scope of the basic institutional structures then his actions as an individual cannot affect the structure of the institutional scheme. ${ }^{43}$ The problem of partiality is a concern of justice between individuals and falls outside the scope of concern for the type of cosmopolitanism employed here.

To illustrate, imagine a society where it is legally permissible for a man to beat his wife. While demanding successfully that the man cease beating his wife may change the effects of injustice occurring between the two individuals, the absence of the harm does not change the structure of the legal institution itself. By escaping from the man's abuse, the woman is no longer enduring harm caused by her husband's beatings. But until the legal institution is changed, it remains permissible for the man to continue beating his wife. Thus, while the woman is no longer a victim of direct harm, the institution under which she operates remains unjust. ${ }^{44}$ An institutional scheme is unjust as long as there is an alternative scheme that improves fairness for all. In this example, for instance, the current scheme is unjust because there is an alternative scheme available, namely one that prohibits spousal abuse.

Again, institutional moral cosmopolitanism is concerned with the design of a just institutional scheme. Thus, even if individuals in the United States are no longer participating in the practices of slavery or colonialism which caused past harm to individuals in Sierra Leone, so long as the global institutional scheme unfairly benefits more developed countries over less developed countries, and an alternative scheme guaranteeing an improved level of fairness for all is possible, we are guilty of participating in an unjust institutional scheme. Notice that a less developed country is no less guilty than a more developed country of ignoring its duty to reform the global institutional scheme. This duty applies to all members of the community.

43. Unless of course his actions are directed toward reforming the scheme itself.

44. See Thomas W. Pogge, Realizing Rawls 109-207 (1989) (distinguishing between the concepts of individual and institutional justice). 


\section{A. Human Rights and Global Health Inequalities}

Human rights exist only insofar as there are social institutions to recognize and enforce protection of these rights against violators. ${ }^{45}$ Before 1920, if a woman arrived at a polling place in the United States on Election Day claiming she had a right to vote, there would have been no institution recognizing her claim and thus nobody to ensure that she could act on her claim. Because she would not have been able to act on her claim, the right that she claimed to have would not exist.

However, today when a woman goes to vote she can claim and act on her right to vote. If she is denied her right because she is a woman, she can rest assured that her claim will be recognized by the courts and enforced by institutional bodies, thus ensuring that she is able to act. The point here is that the courts are an example of the kind of social institution needed to provide an individual the ability to act on a rights claim. Without this kind of institution, an individual still may have a claim but will have no protection that enables her to realize her intended action. Insofar as human rights are dependent on the existence of institutions, the extension of human rights to all human beings on a global level requires the existence of a global institutional scheme in which everyone participates.

Most often, human rights violations concern the direct violation of one individual's right by another. ${ }^{46}$ When prisoner $\mathrm{P}$ is tortured and beaten to death by guard $\mathrm{G}$, individual $\mathrm{G}$ has blatantly violated individual P's right to life and his right not to be tortured. These types of human rights violations, where one individual directly harms another, are considered morally impermissible due to the harm one individual causes to another. Global health inequalities are not the subject of this type of human rights violation.

Health inequalities between nations result from indirect violations of human rights. They are indirect because they arise from systemic and unjust economic, social, and legal institutions. To illustrate, consider the hypothetical country "Corrupt." Although all citizens support Corrupt by paying income taxes, the government provides only its wealthiest citizens with excellent health care, housing, and education and ignores

45. This interpretation of rights is known as rights externalism. See Derrick Darby, Two Conceptions of Rights Possession, 27 SOC. THEORY \& PRAC. 387, 387-417 (describing a more indepth contemporary treatment of rights externalism); see also REX MARTIN, A SYSTEM OF RIGHTS 303-22 (1993); see generally TOM CAMPBELL, RIGHTS: A CRITICAL INTRODUCTION (2006).

46. Examples include torture at Guantanamo Bay and medical experimentation on prisoners in Nazi Germany. 
the rest of the population. As a result, all but the wealthiest citizens of Corrupt suffer from high rates of mortality, disease, and skill deficits. "Money" is one of the wealthiest individuals living in Corrupt. He is healthy, well-educated, and lives in an immaculate house overlooking the ocean. Money does not directly violate the rights of Corrupt's impoverished and ignored citizens. However, the system of government that Money supports does not treat its citizens fairly. By depriving all but the wealthy reasonable access to housing, healthcare, and education, the impoverished are denied some of their most basic human rights and are subject to an unjust institutional scheme. Although Money is not directly responsible for the suffering of the impoverished, through his participation in and benefit from a scheme of unjust institutions, he indirectly harms his fellow citizens.

Reference to the corruption or inefficiency of a country's government is often employed as the primary explanation for poverty in less developed countries. ${ }^{47}$ The United Kingdom's Department for International Development (DFID) report on Sierra Leone attributes poor governance as the major cause of poverty indicators such as sickness, disease, high mortality rates, and starvation. ${ }^{48}$ The reasoning employed to reach this conclusion is as follows: Poverty is a massive problem in Sierra Leone, reflected by the high rates of HIV and disease prevalence, infant and maternal mortality rates, and starvation. ${ }^{49}$ Poverty in Sierra Leone is caused by poor governance. ${ }^{50}$ Thus, relieving poverty in Sierra Leone requires better governance. ${ }^{51}$ From this conclusion, the DFID assumes a commitment to assist the government of Sierra Leone with development. The report is based on the premise that because the government of Sierra Leone is not able to make sufficient progress towards eradicating poverty on its own, partnerships between Sierra Leone and other countries are necessary to eradicate the poverty endemic to it. The report concludes that the DFID and the European Community can contribute to the reduction of infant and maternal mortality, HIV, starvation, and so on by assisting the government with developing

\footnotetext{
47. See DeP'T FOR INT'L DeV., SIERRA LEONE FACT SHEet 1, available at http://www.dfid.gov.uk/pubs/files/Sierra-leone-factsheet.pdf (detailing how Sierra Leone's government contributes to social ills).

48. Id. (describing the effects of poor governance).

49. See id.

50. Id.

51. See id. ("People suffer when governments do not allow participation in political life, provide access to justice, deliver adequate public services or control corruption.").
} 
strategies for eradicating poverty and by providing financial support to assist with the implementation of these strategies. ${ }^{52}$

The DFID report, like many others reporting on the causes of poverty in less developed countries, relies on the underlying assumption that poverty in less developed nations is a result of unjust or inadequate institutions within those nations. Yet, while it may be true that individuals in countries such as the United Kingdom are not violating the human rights of individuals in Sierra Leone directly, is it safe to assume that citizens of other countries are not indirectly violating such rights?

This is where the framework of institutional cosmopolitanism is brought to bear. Sierra Leone is one of the world's richest countries in terms of natural resources and minerals, including gold, diamonds, and rutile. ${ }^{53}$ A lack of financial resources by native land inhabitants prevents many citizens of Sierra Leone from possessing the equipment necessary to extract and profit from the sales and export of these precious minerals. Alluvial gold mining, or panning for gold, is a frequent practice of many native Sierra Leoneans. Many diamonds are bought and sold on the black market, while deep mining, which requires costly heavy machinery and generates some of the most valuable minerals, is practiced legitimately by companies primarily from outside of Sierra Leone, including the United States and the United Kingdom. While the government collects a three percent royalty on all diamond exports, ninety-seven percent of the profit generated from the minerals leaves the country. ${ }^{54}$ The Mines and Minerals Act of 2004 established new guidelines for the distribution of mineral licenses in Sierra Leone, and the Peace Diamond Management Policy (IDMP) and the Peace Diamond Alliance (PDA) were developed in 2005, funded in part by the U.S. Agency for International Development, in cooperation with Global Witness, the DFID, the DeBeers Group, and the Rapaport Group of New York, to reform policy in the diamond sector. Even with these improvements, the smallest diamonds exported from Sierra Leone and then sold in rings at a Wal-Mart in the United States are bought

52. See id. at 3 ("Aid has been relatively fragmented.... Initiatives to improve this include a multi-donor budget support programme... and donors working together on development programmes such as public financial management and health.").

53. See Omayra Bermứdez-Lugo, The Mineral Industries of Liberia and Sierra Leone, in 3 2006 U.S. Geological Survey Minerals Yearbook 24.1, 24.3 (2008) (noting that the "[d]iamond was the most significant mineral commodity" in Sierra Leone and "the Sierra Rutile Mine was one of the world's leading producers of ilmenite and rutile").

54. George J. Coakley, The Mineral Industry of Sierra Leone, in 32004 U.S. GEOLOGICAL SURVEY MINERALS YEARBOOK 34.1, 34.1 (2005). 
legitimately by U.S. diamond miners for $\$ 30$ USD $^{55}$ While these thirtydollar diamonds will sell in the United States at a retail cost of approximately $\$ 1500$ USD, they will earn the government of Sierra Leone a mere ninety cents. ${ }^{56}$ The ratio of profit generated within the United States compared to the profit collected by the government of Sierra Leone is outrageously disparate. While the mining and sales of diamonds by U.S. miners is legitimate, it is not just.

One way to show that an institutional scheme is unjust is to provide an alternative scheme that produces a more just system of institutions. Recall that since the basic institutional structures of society are not directly affected by the actions of individuals, individual choice does not affect institutional justice. Thus, whether or not every American possesses a diamond or gold from Sierra Leone is irrelevant to whether an individual participates in an unjust economic scheme as described above. The majority of the profit produced by the diamonds is absorbed into the U.S. economy and very little is reinvested back into Sierra Leone. Through taxation, part of the profits generated by the diamonds become redistributed to citizens in both countries in the form of goods and services such as public education, roads, and sewer systems, but Americans enjoy a majority of the economic benefit from the overall economic transaction. Thus, because of the structure of the overall institutional scheme, U.S. citizens disproportionately benefit from Sierra Leone's natural resources.

In other words, while not directly harming a child in Sierra Leone, an American citizen's participation in an unjust institutional scheme may cause serious harm to a child in Sierra Leone indirectly. Institutional moral cosmopolitanism is concerned with these types of social, legal, and economic institutions that make up institutional schemes that indirectly cause harm to individuals in other parts of the world.

Economic institutions are connected intimately to a larger scheme of social, legal, and political institutions. For instance, the lack of adequate export taxes to generate profit for the government of Sierra Leone contributes to the lack of electricity, paved roads, and clean water across the country, which in turn is partially responsible for the lack of construction and maintenance of adequate hospitals and schools. A lack of health care, education, and infrastructure generates political and civil unrest, which in turn contributes to the instability of political parties, which perpetuates corruption of party leaders. Poverty is a vicious cycle.

55. Interview with U.S. Diamond Miners, in Sierra Leone (July 28, 2008).

56. Id. 
While foreign aid in the form of medical supplies, food, and public infrastructure provides temporary relief to the impoverished, it is a shortterm cure for the symptoms of a much larger scheme of underlying issues concerning the problem of poverty. The case of diamonds and gold in Sierra Leone is only an example of the effects of such a scheme. The same case can be made for sweat shops in China, rubber exports across the west coast of Africa, and oil refineries in the Middle East.

\section{B. The Impact of Globalization on Social and Political Boundaries ${ }^{57}$}

Globalization has made indirect violations of human rights possible, regardless of how far apart we are physically. ${ }^{58}$ As the ease with which goods and services can be exchanged by nations and institutions across the world increases, so does the possibility that unjust schemes will develop. ${ }^{59}$ The exchange of goods, services, and capital that comprises the world's international economic institutions connects most everyone into a global community. In conjunction with the development of the International Courts, the United Nations, and other worldwide diplomatic institutions, these social, political, and economic institutions bring all human beings closer to the realization of a global institutional scheme. ${ }^{60}$

As participants in an institutional scheme that promotes unjust inequality, we all are responsible indirectly for the violation of human rights. Since we as individuals have a duty, as Pogge puts it, "not to cooperate in the imposition of unjust practices," we in turn have an obligation to promote an institutional scheme that respects the rights of all members of our global community. ${ }^{61}$ These rights include the right to

57. See Pogge, Cosmopolitanism, supra note 40 , at 48 (developing a framework to "promote moral progress" and "gradual global institutional reform").

58. See, e.g., Thomas W. Pogge, World Poverty and Human Rights 33 (2002) [hereinafter POGGE, WORLD POVERTY] ("In the contemporary world, human lives are profoundly affected by non-domestic social institutions - by global rules of governance, trade, and diplomacy, for instance.").

59. See id. ("These institutional interconnections-an important aspect of so-called globalization-render obsolete the idea that countries can peacefully agree to disagree about justice....").

60. See id. at 49 ("[P]lausible reforms of [global institutional] factors could greatly advance the realization of human rights."). Global economic institutions include multinational corporations such as Hewlett Packard, Apple, Toyota, Nike, Nintendo, Pepsi, Volkswagen, Wal-Mart, Johnson \& Johnson, Shell, and Costco; international services such as the Red Cross, Peace Corps, the World Bank, the International Monetary Fund, and the World Wildlife Federation; the stock market; the international systems of trade and commerce; international aid organizations such as the United States Agency for International Development (USAID), World Vision, Save the Children, and Oxfam International; and diplomatic institutions such as the United Nations.

61. See Pogge, Cosmopolitanism, supra note 40, at 50. 
basic health care. As long as the current institutional scheme limits the possession of this right, we all have a duty to pursue systematic reform that better addresses the health needs of individuals across the world.

This basic theory is built on the underlying assumption that our institutional scheme is causally related to massive inequalities in wealth and power between nations, disparities that are perpetuated by the generation of rules of conduct created by the world's most wealthy nations. Although the impact of other factors contributes to the economic instability of particular countries, it is impossible to calculate the exact amount of effect that the global economic market has on wealth inequalities between specific nations. However, it is fair to assume that the global market contributes significantly to the increasing disparities in wealth between the world's most well-off and least well-off nations.

\section{WHAT IS OWED FOR THE LEGACY OF HISTORICAL INJUSTICE IN SIERRA LEONE}

Sierra Leone is one of the least wealthy nations in the world. The country has one of the lowest rates of life expectancy and the highest rates of infant and maternal mortality, malnutrition, malaria, yellow fever, and dysentery, but has the fewest qualified health professionals of any country worldwide. As such, it is not a surprise that a country with a historical legacy of racial and ethnic injustice that includes colonialism, slavery, and conflict, suffers the most from an unjust global institutional scheme. Although the link between the historical legacy of injustice in Sierra Leone and current health inequalities between Sierra Leone and the United States may not be strong enough to generate compensatory obligations to redress past harms, it does not follow that individuals in differing countries are therefore void of obligations toward one another. In accordance with principles of justice, by participating in the scheme of institutions that comprise the basic structure of society, all members have the duty not to uphold the structure of those institutions if they are unjust. $^{62}$

Since the development of an interconnected global economy and the international courts system, a series of global institutions has emerged. Yet the emergence of this global community has not produced a correlative shift in the way individuals perceive themselves as world citizens. It is often taken for granted that national boundaries are artificial human creations, and that institutional schemes have developed 
as a means for maintaining justice within and between societies contained by these artificial boundaries. Expansion of social, economic, and legal institutions is changing boundaries as interconnections continue to expand across the globe. These changes should be a catalyst for rethinking how we conceive of the boundaries of our moral space.

While a specific scheme of global institutions is beyond the scope of this Article, I claim that there is a possible alternative to our current institutional scheme that includes increased protection and enforcement of human rights by social, economic, and political institutions. Legal recognition and enforcement of human rights on multiple levels ${ }^{63}$ is absolutely necessary for decreasing health inequalities within and between nations, guaranteeing a more robust fulfillment of human rights for all members of our global community. ${ }^{64}$

An institutional scheme that is responsive to the moral demands imposed by globalization certainly entails a reconfiguration of boundaries and a redistribution of sovereignty amongst communities, states, nations, multinational unions, and international diplomacies, as well as a set of well-defined universal rights and a set of basic institutional ground rules. ${ }^{65}$ This is not an argument for a world state with a hierarchical scheme of institutions where an international body possesses supreme authority over all others. ${ }^{66}$ An institutional scheme that is appropriate to the reduction of health inequalities is one in which sovereignty is distributed widely, so that all individuals matter significantly with regards to the process by which decisions are made in the context of global matters.

63. There have been a number of proposed schemes for distributing legal protections. See generally Sudhir Chella Rajan, Is Democracy Possible, Part II: Cosmopolitan Ideas and the Problem of Global Political Community (2005) (unpublished manuscript), available at http://ssrn.com/abstract=956150. See also Pogge, Cosmopolitanism, supra note 40.

64. For more on the enforcement of international human rights, see generally SHIV R.S. BEDI,

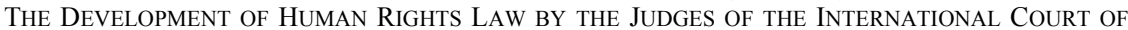
Justice (2007); JaCk Donnelly, InTERnational Human Rights: Dilemmas IN World Politics (2007); Hurst Hannum, InTERnational Human Rights: Problems of LaW, Policy, and Practice (2006); Human Rights: International Protection, Monitoring, ENFORCEMENT (Janusz Symonides ed., 2003). For more on reconfiguring international boundaries see generally Pogge, Cosmopolitanism, supra note 40.

65. While the Universal Declaration of Human Rights lays out an extensive list of rights, very few of those are realized in less well-off countries such as Sierra Leone.

66. See generally Pogge, World POVerty, supra note 58. For a thoughtful treatment of international hierarchy, see Paul K. MacDonald \& David A. Lake, The Role of Hierarchy in International Politics, 32 INT’L SECURITY 171-80 (2008). 


\section{CONCLUSION}

A commitment to justice requires that individuals recognize their obligations to reform unjust institutions in which they participate. Fulfilling this obligation requires active participation in the reform of our current global institutional scheme. Demanding transparency and fairness in the exchange of goods and services on a global level would be the first step, but comprehensive reform will require restructuring our global institutions so that individuals are fairly represented and that all nations participate equally in the maintenance of the overall structure of our global institutional scheme.

Reparations are not an appropriate measure for addressing health inequalities in Sierra Leone, as reparations imply a guilty party responsible for providing redress to the victim of a past wrong. For the case of Sierra Leone, although its historical legacy is littered with injustice, it is not clear who is responsible for paying back what is owed, or how much the legacy of historical injustice is implicated in the formation of health inequalities endemic to Sierra Leone. However, this Article demonstrates that regardless of Sierra Leone's legacy of injustice, our current interconnected global institutional scheme generates duties for all persons to reform institutions that are unjust. In our current global scheme, this means reforming specifically the unjust economic institutions that currently are permitting countries such as Sierra Leone to plunge further into poverty. Without reforming current economic policies and strictly monitoring and enforcing economic exchange between Sierra Leone and other countries, the health and welfare of inhabitants of nations such as Sierra Leone that are rich in resources but lacking in development are bound to experience continual decline. 